\title{
Study of Serum Creatine Kinase and Lactate Dehydrogenase to Assess Muscular Involvement in Hypothyroidism
}

\author{
Reena $\mathrm{R}^{1}$, Manjula KS ${ }^{2}$, Priyadarshini $\mathrm{KS}^{3}$, Usha $\mathrm{SMR}^{4}, \mathrm{HV}$ Shetty ${ }^{5}$
}

\begin{abstract}
Background: Hypothyroidism is one of the most commonly occurring endocrine disorders, worldwide. The disorder is associated with a wide range of muscular involvement varying from myalgia to true myopathy. Biochemical parameters such as serum Creatine Kinase (CK), a sensitive marker of muscle damage and serum Lactate Dehydrogenase (LDH), a general marker of tissue damage can be measured to assess the muscular involvement in hypothyroidism. In this study serum CK and LDH activities to assess the muscular involvement in hypothyroidism and to evaluate their relationship with $\mathrm{T}_{3}, \mathrm{~T}_{4}$ and TSH.

Materials and methods: Fifty, clinically diagnosed hypothyroidism patients with symptoms suggestive of muscle involvement were taken as cases and fifty sex and age matched, apparently healthy volunteers with normal thyroid function tests (TFT) were taken as controls. Biochemical estimations of triiodothyronine $\left(\mathrm{T}_{3}\right)$, thyroxine $\left(\mathrm{T}_{4}\right)$, thyroid stimulating hormone $(T S H)$, serum CK and serum LDH were done.

Results: $T_{3}, T_{4}$ levels and serum CK and LDH activities were within the reference range in both the study groups. In seven cases high TSH with low $\mathrm{T}_{4}$ values were observed. Significant difference in serum CK and LDH activities were observed in these seven cases compared to rest of the forty-three cases. Even though there was no significant difference among the study groups (cases and controls), a weak positive correlation of CK, LDH with TSH levels and weak negative correlation with $\mathrm{T}_{3}$ and $\mathrm{T}_{4}$ levels were observed.

Conclusion: Hormone replacement therapy shall be optimized to treat muscular involvement if serum CKand LDH activity is found to be elevated with low $\mathrm{T}_{4}$ levels, where as normal serum $\mathrm{CK}$ and $\mathrm{LDH}$ activity with normal $\mathrm{T}_{4}$ levels indicates that the thyroid treatment is optimized (serum $\mathrm{T}_{3}$ and $\mathrm{T}_{4}$ levels has come to the reference range though TSH is mildly elevated) and if the subject is still complaining of muscular symptoms, then other underlying causes for muscular involvement shall be ruled out.
\end{abstract}

Key Words: Creatine Kinase (CK), Hypothyroidism, Lactate Dehydrogenase (LDH), Thyroid stimulating hormone (TSH).Thyroxine (T4), Triiodothyronine (T3).

Indian Journal of Medical Biochemistry (2019): 10.5005/jp-journals-10054-0103

\section{INTRODUCTION}

Thyroid diseases are common worldwide. In India too, there is a significant burden of thyroid diseases. According to a projection from various studies on thyroid disease, it has been estimated that about 42 million people in India suffer from thyroid diseases ${ }^{1}$. The thyroid disorders are broadly classified into 1) hypothyroidism and 2) hyperthyroidism. In India prevalence of hypothyroidism is $3.9 \%$. In women, the prevalence is higher, at $11.4 \%$, when compared with men, in whom the prevalence is $6.2 \%{ }^{1}$.

Thyroid hormones regulate our body's metabolism and influence virtually every organ system in the body. They increase the activity of membrane-bound $\mathrm{Na}^{+}-\mathrm{K}^{+}$ATPase, increase heat production and stimulate oxygen consumption (calorigenesis) in muscle, increase muscle demand for vitamins and enhance muscle sensitivity to circulating catecholamines ${ }^{2}$.

Deficiency of thyroid hormones in hypothyroidism slows down the metabolic functions. In muscle, reduction in mitochondrial oxidative capacity and beta-adrenergic receptors as well as the induction of an insulin-resistant state may be seen ${ }^{3}$. Histologically the muscle fibres show enlargement, focal myofibrillar degeneration, increase in central nuclei, glycogen accumulation and mitochondrial aggregations and type II fibre atrophy ${ }^{3,4}$. These metabolic disturbances results in change in distribution of muscle fibers from fast twitch fibers to slow twitch fibers causing delayed muscle contraction and relaxation which is seen in myopathy. Decrease in muscle carnitine in hypothyroidism may also contribute to thyroid myopathy ${ }^{5}$. True myopathy is a primary muscle involvement
${ }^{1,2}$ Assistant Professor, ${ }^{3}$ Professor, ${ }^{4}$ Professor and Head, ${ }^{5}$ Ex-Professor and Head

Department of Biochemistry, RajaRajeswari Medical College and Hospital, Bengaluru, Karnataka, India

Corresponding Author: Reena R, Assistant Professor, Department of Biochemistry, RajaRajeswari Medical College and Hospital, Bengaluru, Karnataka, India, e-mail: drreenarmahendra@gmail.com

How to cite this article: R Reena, KS Manjula, KSPriyadarshini, SMRUsha, HV Shetty. Study of Serum Creatine Kinase and Lactate Dehydrogenase to Assess Muscular Involvement in Hypothyroidism. Indian J Med Biochem 2019;23(2):273-277.

Source of support: Nil

Conflict of interest: None

characterized by slowed muscle contraction and relaxation, muscle pain, proximal muscle weakness, sluggish ankle jerks and absence of sensory involvement ${ }^{6}$. Pain on muscle exertion is due to defective carbohydrate metabolism?.

Thus, in addition to the characteristic clinical picture, hypothyroidism may be associated with a wide range of muscle disturbances varying from myalgia to a true myopathy. Muscular symptoms like weakness, myalgia, stiffness, cramps and easy fatigability is seen $30-80 \%$ of patients ${ }^{4}$.

To assess the muscular involvement in these patients, biochemical tests such as Creatine Kinase (CK) or Creatine phosphokinase (CPK) and Lactate Dehydrogenase (LDH) can be used. Of these, CK is the most sensitive indicator and measure of

(0) The Author(s). 2019 Open Access This article is distributed under the terms of the Creative Commons Attribution 4.0 International License (https://creativecommons. org/licenses/by-nc/4.0/), which permits unrestricted use, distribution, and non-commercial reproduction in any medium, provided you give appropriate credit to the original author(s) and the source, provide a link to the Creative Commons license, and indicate if changes were made. The Creative Commons Public Domain Dedication waiver (http://creativecommons.org/publicdomain/zero/1.0/) applies to the data made available in this article, unless otherwise stated. 
muscle damage and LDH is a general indicator of tissue damage. CK is an enzyme found mainly in the heart, brain, and skeletal muscle. When the total CK (CK MM isoenzyme is $80 \%$ of total CK level) is very high, it usually means there has been injury or stress to the skeletal muscle tissue. High CK levels may be seen in patients who have stroke, dermatomyositis or polymyositis, heart attack, myocarditis, muscular dystrophies and myopathy. Other conditions that may cause elevated CK levels are hypothyroidism, hyperthyroidism and pericarditis following a heart attack. Lactate Dehydrogenase (LDH) is an intracellular enzyme found in heart, blood cells, lungs, kidney, placenta, pancreas, liver and skeletal muscles. LDH is a general indicator of the existence and severity of acute or chronic tissue damage.

Literature search shows that the prominence of muscle symptoms correlates fairly closely with the degree and duration of hypothyroidism ${ }^{6}$ and the serum CK level may be elevated in hypothyroidism: and can be an important differential diagnosis for raised serum CK. Case reports ${ }^{6,7}$ shows that hypothyroidism can present with muscular symptoms alone with minimal or without any classical symptoms and signs of hypothyroidism.

In this regard we estimated the activities of serum CK and LDH to assess the muscular involvement and to know their correlation with the circulating levels of $\mathrm{T}_{3}, \mathrm{~T}_{4}$ and TSH in hypothyroidism.

\section{Materials AND Methods}

Fifty, clinically diagnosed cases of hypothyroid patients, in the age group of 18-50 years with clinical symptoms of muscular involvement, irrespective of the duration of the disease and treatment, attending medical OPD at RRMCH, Bengaluru were the study cases. Muscular symptoms include weakness, myalgia, stiffness, cramps, easy fatigability and myopathy. Subjects with serum CK elevation for other causes like muscular dystrophies, acute chest pain, myocarditis, stroke, epilepsy, recent history of intramuscular injections, strenuous exercises, trauma or accidents and other medical conditions which alter serum CK were excluded from the study. Fifty, age and sex matched, apparently healthy volunteers with normal TFT, in the same age and sex group without muscular symptoms were the study controls.

\section{Method of Collection of Data}

Institutional ethical committee clearance was obtained. After informed consent, under full aseptic precautions, $5 \mathrm{ml}$ of venous sample was collected from the control and cases. TFT (Total $\mathrm{T}_{3}$, Total $\mathrm{T}_{4}$ and TSH) was estimated by chemiluminescence method (CLIA). Serum CK and LDH was estimated by kinetic spectrophotometric method (Accucare kits).

\section{Statistical Analysis}

This is a descriptive study. The data obtained was analyzed statistically using One way Anova calculator for independent measures. $p$ value $>0.1$ considered not significant, $p<0.05$ moderately significant, $p<0.001$ highly significant. Pearson's correlation coefficient was used to find out the correlation. The Pearson correlation coefficient is used to measure the strength of a linear association between two variables, where the value $r=1$ mean a perfect positive correlation and the value $r=-1$ means a perfect negative correlation and value nearer to zero the relationship is weaker.

\section{ResUlts}

This study was carried out in 50 clinically diagnosed cases of hypothyroidism with symptoms suggestive of muscular involvement and fifty apparently healthy volunteers. Among fifty hypothyroid cases 45 cases (92\%) were recently diagnosed (within 1 year) and duration of illness in remaining five cases was more than a year. All the fifty cases were on thyroid hormone replacement therapy and complained of mild muscular symptoms (myalgia, pain in the shoulders/thighs/climbing up the stairs). There was no case of severe muscular symptoms (myopathy) in our study population (Table 1). Majority of the cases (97\%) and controls (93\%) were females (Fig. 1) in the mean age group of $33 \pm 12$ years and $34 \pm 12$ years respectively ( $p$ value $=0.575$ ).

$\mathrm{T}_{3}$ and $\mathrm{T}_{4}$ was within the reference range whereas TSH was high in cases. TFT was within the reference range in controls. There was significant difference $(p=0.00001)$ in TFT values among cases and controls (Table 2).

TSH was elevated and $T_{3}$ and $T_{4}$ levels were within reference range in 43 cases and in 7 cases TSH was $>100 \mu \mathrm{lU} / \mathrm{ml}$ and $\mathrm{T}_{4}$ levels were low and $T_{3}$ within reference range but towards lower limit (Table 3).

Serum Total CK levels in cases and controls were $73 \pm 36 \mathrm{U} / \mathrm{L}$ and $64 \pm 37 \mathrm{U} / \mathrm{L}$ respectively. The levels were within the reference range of CK (Serum CK reference range: 25-192 U/L) in both the study groups (Fig. 2). There was no significant difference among the study groups ( $p$ value $=0.38$ ).

Serum LDH levels in cases and controls were $120 \pm 42 \mathrm{IU} / \mathrm{L}$ and $123 \pm 35 \mathrm{IU} / \mathrm{I}$ respectively. The levels were within the reference range of $\mathrm{LDH}$ (Serum LDH reference range: 105-333 IU/L) in both the study groups (Fig. 3). There was no significant difference among the study groups ( $p$ value $=0.77$ ).

In seven cases whose TSH was $>100 \mu \mathrm{lU} / \mathrm{mL}$, mean total CK was $103 \pm 55 \mathrm{U} / \mathrm{L}$. Among these seven cases, in one case high CK (378 IU/L) and LDH (217IU/L) activity was observed. When compared to rest of the cases $(n=43)$ there was significant difference $(p<0.069)$ in $C K$ values at $p<0.01$ and no significant difference when LDH activities are considered.

Even though there was no significant difference in any of the study parameters between the study groups, in cases a weak positive correlation between $\mathrm{CK}$, LDH levels with TSH levels and weak negative correlation with $T_{3}$ and $T_{4}$ levels was observed (Table 4, Fig. 4).

Table 1: Muscular symptoms in hypothyroid cases

\begin{tabular}{lll}
\hline Sl. No. & Muscular symptoms & No. of cases \\
\hline 1. & $\begin{array}{l}\text { Easy fatigability during and following } \\
\text { normal house hold work }\end{array}$ & 07 \\
2. & $\begin{array}{l}\text { Pain in the limbs following walking for 1 or } \\
\text { 2 kilometers }\end{array}$ & 11 \\
& $\quad \begin{array}{l}\text { Pain in the thighs during walking for 1 or 2 } \\
\text { kilometers }\end{array}$ & 17 \\
4. & Pain in the thighs while climbing the stairs & 10 \\
5. & Nonspecific muscle pain & 05 \\
6. & Myopathy & 00 \\
7. & Total number of cases & 50 \\
\hline
\end{tabular}




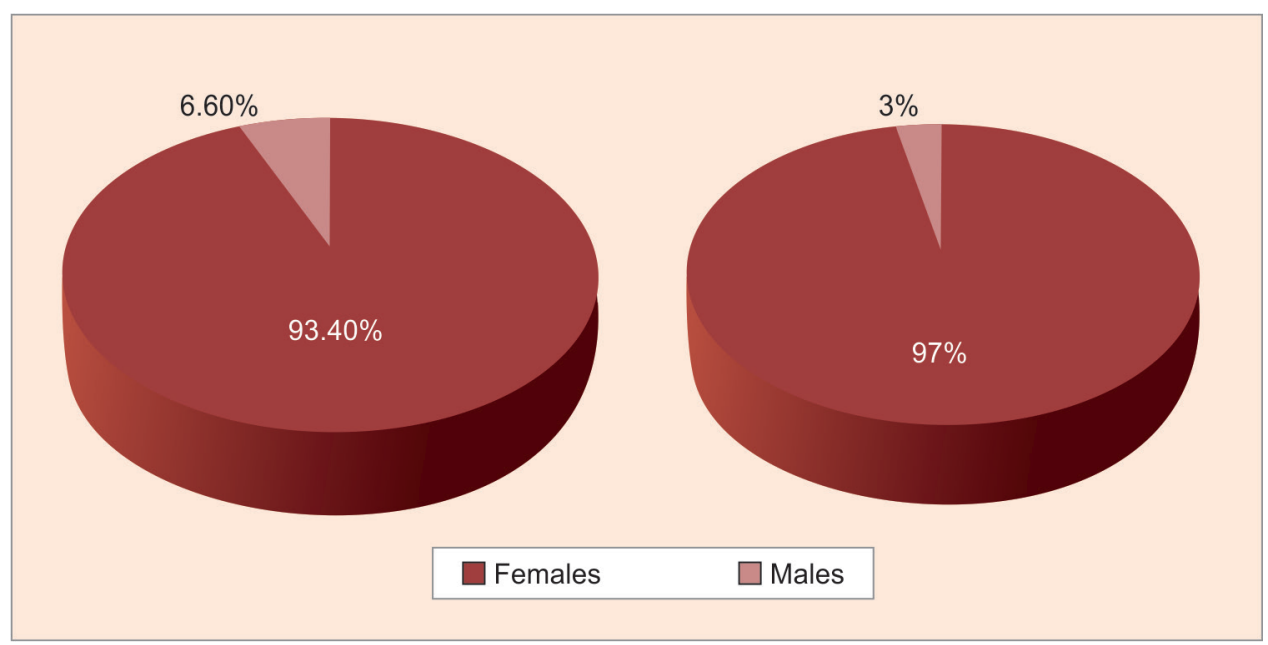

Fig. 1: Sex distribution among controls and cases

Table 2: Thyroid profile values among the study groups

\begin{tabular}{llll}
\hline $\begin{array}{l}\text { Study groups } \\
\text { (Ref range) }\end{array}$ & $\begin{array}{l}T_{3} \\
(69-215 \mathrm{ng} / \mathrm{dl})\end{array}$ & $\begin{array}{l}T_{4} \\
(6-12 \mu \mathrm{g} / \mathrm{dL})\end{array}$ & $\begin{array}{l}\text { TSH } \\
(0.34-5.6 \mu \mathrm{lU} / \mathrm{ml})\end{array}$ \\
\hline $\begin{array}{l}\text { Controls } \\
\text { (Mean } \pm \mathrm{SD})\end{array}$ & $120 \pm 25$ & $9.17 \pm 1.4$ & $2.63 \pm 1.25$ \\
$\begin{array}{l}\text { Cases } \\
\text { (Mean } \pm \mathrm{SD})\end{array}$ & $89.9 \pm 29$ & $6.62 \pm 2.5$ & $43.8 \pm 50.29$ \\
\begin{tabular}{l} 
P value \\
\hline
\end{tabular} & 0.00001 & 0.00001 & 0.00001 \\
\hline
\end{tabular}

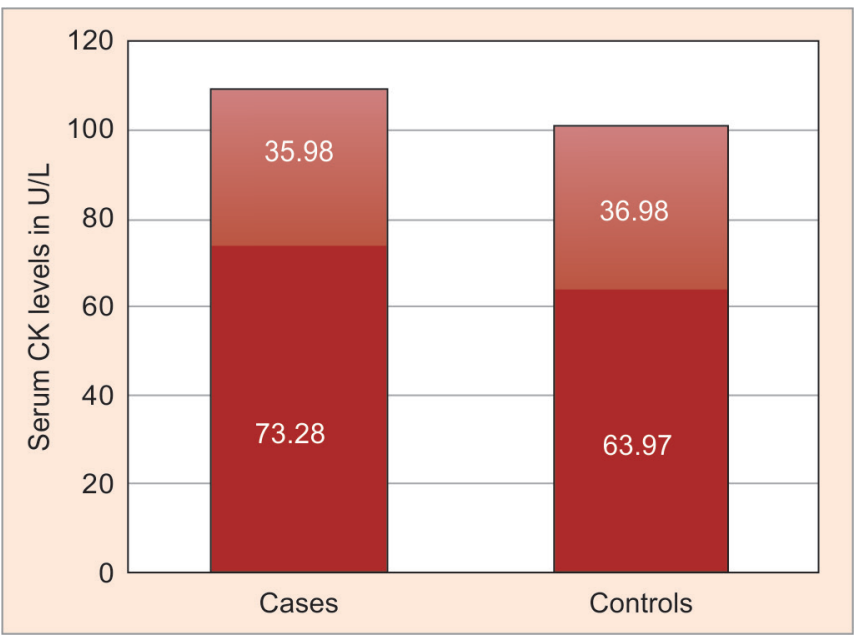

Fig. 2: Bar diagram showing serum CK levels in controls and cases

Table 4: Pearson correlation coefficient between TFT and study parameters (CK and LDH)

\begin{tabular}{lllll}
\hline & \multicolumn{2}{c}{ Cases (rvalues) } & \multicolumn{2}{c}{ Controls (rvalues) } \\
\cline { 2 - 5 } TFT & CK & LDH & CK & LDH \\
\hline $\mathrm{T}_{3}$ & -0.3302 & -0.3302 & 0.0812 & -0.1355 \\
$\mathrm{~T}_{4}$ & -0.3342 & -0.2452 & -0.1038 & 0.0236 \\
$\mathrm{TSH}$ & 0.3475 & 0.3445 & -0.0479 & -0.0587 \\
\hline
\end{tabular}

Table 3: TFT levels and study parameters activities in cases

\begin{tabular}{|c|c|c|c|}
\hline $\begin{array}{l}\text { TFT and study } \\
\text { parameters }\end{array}$ & $\begin{array}{l}\text { In cases }(n=43) \\
T S H<100 \mu \mathrm{IU} / \mathrm{mL}\end{array}$ & $\begin{array}{l}\text { In cases }(n=6) \\
T S H>100 \mu l U / m L\end{array}$ & Pvalue \\
\hline $\begin{array}{l}\text { TSH } \\
(0.34-5.6 \mu \mathrm{lU} / \mathrm{mL})\end{array}$ & $19 \pm 19$ & $127 \pm 22$ & $<0.00001$ \\
\hline $\begin{array}{l}T_{3} \\
(69-215 \mathrm{ng} / \mathrm{dL})\end{array}$ & $94 \pm 30$ & $76 \pm 23$ & 0.14 \\
\hline $\begin{array}{l}T_{4} \\
(6-12 \mu \mathrm{g} / \mathrm{dL})\end{array}$ & $7.4 \pm 2$ & $3.9 \pm 2.2$ & $\begin{array}{l}0.0003 \\
(<0.001)\end{array}$ \\
\hline CK & $52 \pm 24$ & $103 \pm 55$ & 0.0069 \\
\hline LDH & $114 \pm 38$ & $139 \pm 50$ & 0.164 \\
\hline
\end{tabular}

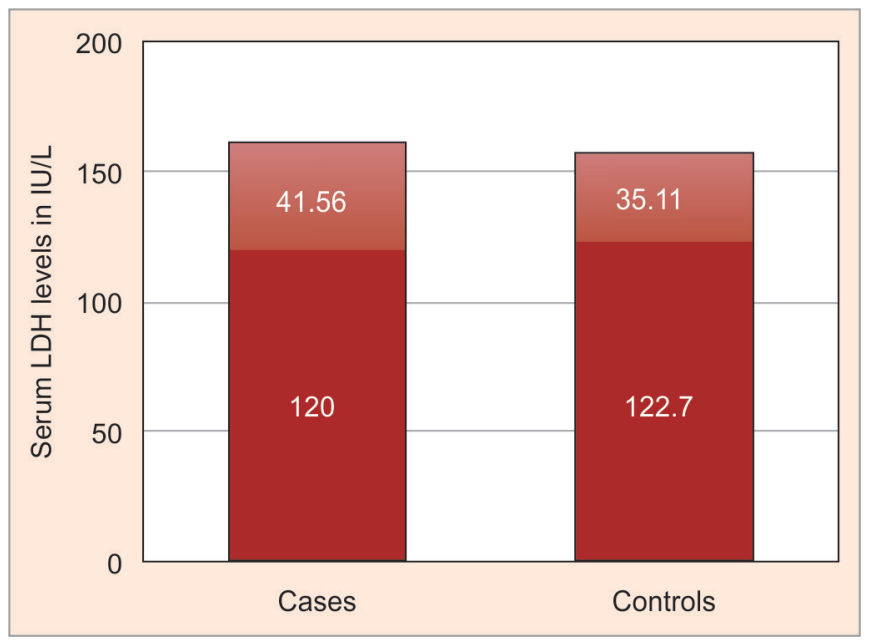

Fig. 3: Bar diagram showing serum LDH levels in controls and cases

\section{Discussion}

Hypothyroidism symptoms linger despite medications ${ }^{8}$. Following thyroid hormone replacement therapy mild muscular symptoms like aches, cramps, stiffness may take several weeks and severe muscular symptoms (weakness/myopathy) may take longer to 


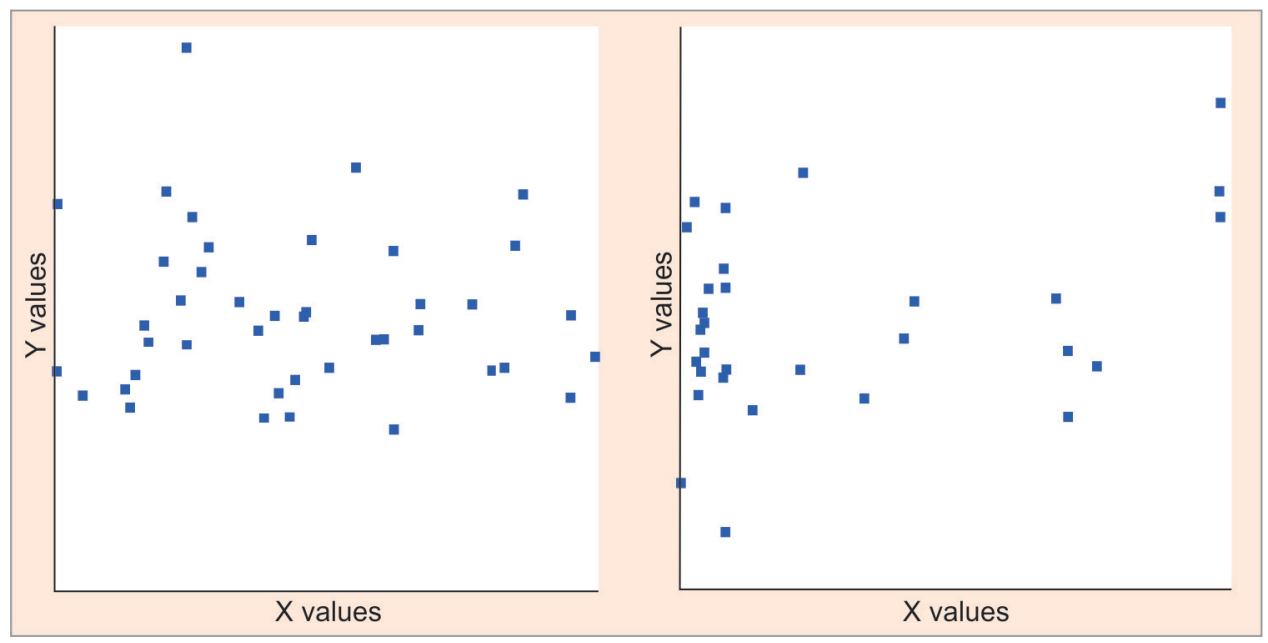

Fig. 4: Correlation co-efficient between TSH and LDH in controls and cases ( $X=T S H, Y=L D H)$

resolve ${ }^{9}$. Though there is no significant increase in mortality or morbidity this may reflect in quality of patient life. In this context we have estimated CK and LDH in treated hypothyroid patients with symptoms suggestive of muscular involvement and correlated with thyroid profile.

In our study CK and LDH were well within the reference range in both the study groups (cases and healthy volunteers). There was no significant difference among study groups with respect to both the parameters.

Among fifty cases, in forty-three cases (86\%) TSH level was mildly elevated; $T_{3}$ and $T_{4}$ levels were within the reference range (towards the lower limit of the reference range). In these cases, we observed normal CK and $\mathrm{LDH}$ activities. In rest of the seven cases (14\%) TSH was high ( $>100 \mu \mathrm{lU} / \mathrm{ml}), \mathrm{T}_{4}$ level was low and $\mathrm{T}_{3}$ levels though normal towards the lower limit of the reference range. In these seven cases average CK activity was $103 \pm 55 \mathrm{IU} / \mathrm{L}(p=0.0069)$ with normal LDH activity. In our study all the cases were clinically diagnosed and treated hypothyroid subjects, biochemical picture of 43 cases simulated subclinical hypothyroidism and seven cases simulated overt hypothyroidism. Hekimsoy $\mathrm{Z} \mathrm{h}$ et $\mathrm{al}^{10}$ in their study observed normal CK levels in subclinical hypothyroidism and controls, high CK levels in overt hypothyroidism. Few authors have observed significant increase in CK levels ${ }^{10-16}$ and both ${ }^{17} \mathrm{CK}$ and LDH in their study population.

Though there was no significant difference in CK and LDH activities among our study groups (cases and controls) we observed a weak positive correlation between study parameters (CK \& LDH) and TSH levels and weak negative correlation between study parameters ( $C K \& L D H)$ and $T_{3}, T_{4}$ levels. This means as the TSH value increases and $\mathrm{T}_{3} \mathrm{~T}_{4}$ value decreases, $C K$ and $\mathrm{LDH}$ activities increases. Like our study findings, positive correlation between CK, LDH levels with TSH levels and negative correlation with $\mathrm{T}_{3}$ and $\mathrm{T}_{4}$ levels was observed by other authors ${ }^{3,14}$.

The serum CK and LDH level depends on the severity of muscular involvement which in turn depends on the severity of hypothyroidism. Thus, the serum enzyme activity of these muscle enzymes correlates with the degree of hypothyroidism. Literature search also shows that in addition to improvement in clinical symptoms, serum CK levels decreases to normal levels when thyroid function tests normalized following thyroid hormone replacement therapy ${ }^{9}$ and hypothyroidism appears to be the only condition, other than muscular dystrophy, in which high levels of CK are sustained in the absence of specific treatment. ${ }^{18}$

Normal serum CK and LDH activity observed in our study shall be due to the fact that, most of the cases were on treatment and their thyroid hormone levels $\left(\mathrm{T}_{3}\right.$ and $\mathrm{T}_{4}$ ) were optimal (though TSH was mildly elevated). If the muscular symptoms persist despite prompt hypothyroid treatment and normal serum CKactivity, other underlying causes for muscular pain like vitamin (Vitamin D, Vitamin B12)/ mineral (Iron) deficiency, fibromyalgia shall be ruled out. ${ }^{19}$

\section{Conclusion}

Hormone replacement therapy shall be optimized to treat muscular involvement if serum CK and LDH activity is elevated with low T4 levels, where as normal serum CK and LDH activity with normal T4 levels indicates that the thyroid treatment is optimized (serum $\mathrm{T}_{3}$ and $\mathrm{T}_{4}$ levels has come to the reference range though TSH is mildly elevated) and if the subject is still complaining of muscular symptoms, then other underlying causes for muscular involvement shall be ruled out.

\section{Limitations and Recommendations}

The limitation of this study is that it is a cross sectional study with small sample size. Total $\mathrm{T}_{3}$ and $\mathrm{T}_{4}$ levels are estimated rather than free $T_{3}$ and $T_{4}$ levels which more reliable.

Recommendations: Serum CK activity shall be measured in treated hypothyroid subjects with and without muscular symptoms and a lower reference range of serum CK levels in hypothyroidism has to be established.

\section{ACKNOWLedgments}

Sincere thanks to all the study subjects, teaching and nonteaching staff of Department of Biochemistry. Special thanks to Dr. Chandrika N. Associate professor, Department of Biochemistry, Chamarajanagar Institute of Medical Sciences, Chamarajanagara, Karnataka.

\section{References}

1. Ambika Gopalakrishnan Unnikrishnan, Usha V Menon. 2011." Thyroid disorders in India: An epidemiological perspective". Indian Journal of Endocrinology and Metabolism.15:6:78-81 
2. Lange.2006." Lange Pathophysiology". Chapter 20. Thyroid Disease. The McGraw-Hill Companies.

3. Saima Mushtaq, Mona.A.Tilak, Malik Rameez Rashid, Sarita A. Shinde, Pradnya J.Phalak. 2014. "Biochemical evaluation of myopathy in Patients of hypothyroidism". Indian Journal of Basic and Applied Medical Research. 3(2); 364-372.

4. Khaleeli AA, Gohil K, McPhail G, Round JM, Edwards RHT. 1983. Muscle morphology and metabolism in hypothyroid myopathy: effects of treatment. J Clin Pathol. 36:519-526.

5. Sinclair C, Gilchrist JM, Hennessey JV.2005. Muscle carnitine in hypo and hyperthyroidism. Muscle Nerve. 32(3):357-59.

6. N P Singh, S Anuradha and S K Agarwal.2001." A young woman with muscle weakness". Postgrad Med J.; 77:266-285.

7. HS Kiran, KA Sudharshana Murthy, AN Aparna 2011. "A young lady with swelling and stiffness of calf muscles". Indian J Endocrinol Metab;15(2): 130-131.

8. Hypothyroidsm symptoms linger despite of medication. ScienceDaily. https://www.sciencedaily.com/releases/2016/10/161012132038.htm

9. Mary Shomon. 2018. "Understanding muscle pain and weakness in thyroid disease". Thyroid Disease. https://www.verywell.com.

10. Hekimsoy Z, Oktem IK. 2005. Serum creatine kinase levels in overt and subclinical hypothyroidism. Endocr Res. 31(3):171-5.

11. KMDS Panag, Gitanjali, Sudeep Goyal. 2012. Evaluation of Creatine Kinase as a Diagnostic Tool for Thyroid Function. Indian Journal of Clinical Practice. 23(4);221-223.
12. ArchanaPrakash, AKLal, KS Negi.2007." Serum Creatine Kinase Activity in Thyroid Disorders".JK Science. Vol.9, No.1.

13. Raju Pandey, Suresh Jaiswal, Jay Prakash Sah, Krishna Bastola, Subadhra Dulal. 2013. "Assessment of Serum Enzymes Level in Patients with Thyroid Alteration Attending Manipal Teaching Hospital, Pokhara". Research and Reviews: A Journal of Life Sciences. 3(1): 1-9.

14. Rekha Nanjundasetty Hemavathi, Anilkumar Hanumanthaiah. 2016. Evaluation of Serum Creatine Kinase Levels in Patients with Hypothyroidism. J. Evolution Med. Dent. Sciences. 05(35); 2053-2055.

15. R. Shanti, M. Vijayalakshmi, R. Mahalakshmi. 2017. Creatine kinase \& lactate dehydrogenase activity in patients with hypothyroidism. International Journal of Clinical Biochemistry and Research. 4(2):182186.

16. Hartl E, Finstere J, Grossegger C, Kroiss A, Stolleberger C. 2001. "Relationship between thyroid function and skeletal muscle involvement in subclinical and overt hypothyroidism". Endocrinologist. 11:217-21.

17. DA McGrowder, YP Fraser, L Gordon, TV Crawford, JM Rawlins. 2011. "Serum Creatine Kinase and Lactate Dehydrogenase activities in patients with thyroid disorders". Niger J Clin Pra. Vol.14: 4: 454-459.

18. P. D. Griffiths.1965." Serum enzymes in diseases of thyroid gland". J. Clin.Path.18, 660.

19. Divakara Kedlaya. 2015. "Hypothyroid myopathy" emedicine. medscape.com/article/313915-overview. 